\title{
ANALISIS PENGARUH BUDAYA ORGANISASI SEKOLAH DAN MOTIVASI KERJA GURU TERHADAP MUTU PENDIDIKAN DI BEKASI
}

\author{
Oleh: \\ Meryati1); Titin Meidarti2); Eka Giovana Asti ${ }^{31}$ \\ Email: Merry.santoso@(atlover.com ${ }^{1}$; ;itin2meidarti@gmail.com ${ }^{2)}$; ekagiovanaasti@yahoo.co.id ${ }^{3}$ \\ Sekolah Tinggi Ilmu Ekonomi IPWI Jakarta, 1,2,3)
}

\begin{abstract}
ABSTRAK
Penelitian ini dilatarbelakangi oleh permasalahan yang dihadapi SD ISLAM TERPADU BAITUL JIHAD Kemang Pratama 2, Bekasi dalam usaha meningkatkan mutu pendidikan. Berbagai usaha telah dilakukan melalui pelatihan dan peningkatan Guru, penyempurnaan kurikulum, pengadaan buku dan alat pelajaran, perbaikan sarana dan prasarana pendidikan serta peningkatan mutu manajemen Sekolah. Namun demikian mutu pendidikan pada SD ISLAM TERPADU BAITUL JIHAD Kemang Pratama 2, Bekasi belum menunjukkan peningkatan yang memadai.

Salah satu faktor lain yang dapat mempengaruhi mutu pendidikan dan menarik untuk diteliti adalah budaya organisasi Sekolah, yang merupakan mekanisme pembuat makna dan kendali pembentuk sikap serta perilaku Guru. Selain itu, faktor motivasi kerja Guru juga merupakan faktor yang dapat mempengaruhi mutu pendidikan.

Populasi dan sekaligus juga sebagai sampel (responden) dalam penelitian ini adalah sebanyak 42 orang Guru. Teknik pengumpulan data menggunakan angket yang di isi oleh responden, kategori jawaban responden penelitian terhadap angket terdiri atas lima skala berdasarkan skala Likert. Pengujian statistik yang digunakan adalah dengan perhitungan uji validitas, uji reliabilitas, koefisien korelasi, koefisien determinasi, uji hipotesa dan analisa regresi. Data yang didapat diolah dengan bantuan menggunakan program SPSS.

Berdasarkan hasil perhitungan dan hasil analisa data, ditemukan bahwa: koefisien korelasi antara Budaya Organisasi Sekolah dan Motivasi Kerja Guru secara bersama-sama terhadap Mutu Pendidikan di SD ISLAM TERPADU BAITUL JIHAD Kemang Pratama 2, Bekasi, adalah positif dengan tingkat hubungan yang sangat kuat, yaitu sebesar 0,902 dan setelah diuji hipotesa dengan uji $F$ korelasi tersebut memiliki hubungan yang signifikan. Kemudian didapatkan hasil uji koefisien regresinya juga menunjukkan hubungan lurus dan positif dilihat dari kontribusi variabel Budaya Organisasi Sekolah dan Motivasi Kerja Guru terhadap Mutu Pendidikan di SD ISLAM TERPADU BAITUL JIHAD Kemang Pratama 2, Bekasi, dengan persamaan regresi, yaitu: $Y=13,191+0,314 X 1+1,552 X 2$.
\end{abstract}

Kata Kunci : Budaya Organisasi Sekolah, Motivasi Kerja Guru dan Mutu Pendidikan

\begin{abstract}
This research is motivated by the problems faced by the school of ISLAM SDAM INTEGRATED SPAIN JIHAD. Kemang Pratama 2, Bekasi in an effort to improve the quality of education. Various efforts have been made through teacher training and improvement, curriculum improvements, procurement of books and instructional tools, improvement of educational facilities and infrastructure and improvement of school management quality. Nevertheless, the quality of education in the school of ISLAM SDAM INTEGRATED SAMITUL JIHAD Kemang Pratama 2, Bekasi has not shown adequate improvement.
\end{abstract}


Facttor that can affect the quality of education and interesting to be examined is the school's organizational culture, which is the mechanism of meaning-making and control of attitude-shaping and teachers'pesonality behavior. Organizational culture is needed to unite each individual within the organization. In addition, Teacher's motivational factors are also factors that can affect the quality of education. Motivation work functions as a strength or power for encouraging a person in achieving the goals and resultting an optimal job. Providing from the principal motivation to the teachers as well as motivations that arise from the teachers themselves in order to achieve job satisfaction, achieving maximum performance and achieving organizational goals for improving the quality of school education.

The population and sample (respondents) in this study were 42 people teachers. Technique of collecting data was using questionnaire to be answered by respondents, category of respondent answer consist of five scale based on Likert scale. Statistic evaluation used consisted of the calculation of validity test, reliability test, correlation coefficient, coefficient of determination, hypothesis test and regression analysis. The data obtained was processed with the help of SPSS program.

Based on the calculation and the results of data analysis, it was found that: the coefficient of correlation between the School's Organization Culture and Teacher Work Motivation collectively to the Quality of Education in the school of ISLAM ISLAMATED SD BAMAMA BAITUL JIHAD Kemang Pratama 2, Bekasi, is positive with a very strong relationship level, of 0.902 and after tested the hypothesis with $F$ test correlation has a significant relationship.

Then obtained the results of regression coefficient test also showed a straight and positive relationship seen from the contribution of the School Organization Cultural Variables and Teacher Work Motivation to the Quality of Education in ISLAM Primary School BAITUL JIHAD Kemang Pratama 2, Bekasi, with regression equation, namely: $Y$ $=13.191+0.314 X 1+1.552 \times 2$.

Keywords: School Organization Culture, Teacher Work Motivation and Education Quality

\section{PENDAHULUAN}

Sekolah sebagai sistem harus menekankan pada proses belajar mengajar sebagai pemberdayaan siswa, yang dilakukan melalui interaksi perilaku pengajar (Guru) dan perilaku siswa, baik di dalam maupun di luar kelas. Karena proses belajar mengajar merupakan pemberdayaan siswa, maka penekanannya bukan sekadar mengajarkan sesuatu kepada siswa dan kemudian menyuruhnya mengerjakan soal agar memiliki jawaban baku yang dianggap benar oleh pengajar, akan tetapi proses belajar mengajar yang mampu menumbuhkan daya kreasi, daya nalar, rasa keingintahuan, dan eksperimentasi-eksperimentasi untuk menemukan kemungkinankemungkinan baru (meskipun hasilnya keliru), memberikan keterbukaan terhadap kemungkinan-kemungkinan baru, menumbuhkan demokrasi, memberikan kemerdekaan, dan memberikan toleransi terhadap kekeliruan-kekeliruan akibat kreativitas berpikir.

Output pendidikan adalah lulusan yang sudah terdidik. Tolak ukur dari lulusan yang sudah terdidik adalah tujuan pendidikan. Artinya, lulusan yang sudah terdidik adalah lulusan yang sudah melalui proses pendidikan dan mencapai tujuan pendidikan. Maka lulusan yang sudah terdidik yang dimaksud adalah orang yang melalui proses pendidikan sudah mengalami perubahan dan peningkatan mutu kemampuan, pengetahuan dan keterampilan baik dari segi kognitif, psikomotor maupun afektif.

Upaya peningkatan mutu merupakan agenda setiap institusi pendidikan. Berkembangnya tuntutan kebutuhan masyarakat terhadap mutu layanan jasa pendidikan merupakan sebuah tantangan baru bagi setiap institusi atau lembaga pendidikan di 
tengah kondisi persaingan yang semakin ketat. Untuk mempertahankan eksistensinya, setiap institusi pendidikan harus memiliki daya saing yang ditunjukkan melalui peningkatan mutu layanannya.

Pada era globalisasi pendidikan merupakan hal yang sangat penting karena pendidikan merupakan salah satu penentu mutu sumber daya manusia. Dewasa ini keunggulan suatu bangsa tidak lagi ditandai dengan melimpahnya kekayaan alam, melainkan pada keunggulan sumber daya manusia yang berkorelasi positif dengan mutu pendidikan. Mutu pendidikan sering diindikasikan dengan kondisi yang baik, memenuhi syarat, dan segala komponen yang harus terdapat dalam pendidikan. Komponen-komponen tersebut adalah masukan, proses, keluaran, tenaga kependidikan, sarana dan prasarana serta biaya.

Mutu pendidikan tercapai apabila input, proses, output, guru, sarana dan prasarana serta biaya pada seluruh komponen tersebut memenuhi syarat tertentu. Namun dari beberapa komponen tersebut yang lebih banyak berperan adalah tenaga kependidikan yang bermutu yaitu yang mampu menjawab tantangan-tantangan dengan cepat dan tanggung jawab.

Sekolah dalam hal ini kepala sekolah, guru dan stakeholder mempunyai tanggung jawab terhadap peningkatan mutu pendidikan di sekolah. Peningkatan mutu pendidikan bukanlah upaya sederhana, melainkan suatu kegiatan dinamis dan penuh tantangan. Pendidikan selalu berubah seiring dengan perubahan zaman. Oleh karena itu pendidikan senantiasa memerlukan upaya perbaikan dan peningkatan mutu sejalan dengan semakin tingginya kebutuhan dan tuntutan kehidupan masyarakat.

Mutu pendidikan atau mutu sekolah tertuju pada mutu lulusan. Sekolah menghasilkan lulusan yang bermutu melalui proses pendidikan yang bermutu pula. Proses pendidikan yang bermutu didukung oleh faktor-faktor penunjang proses pendidikan yang bermutu. Proses pendidikan yang bermutu harus didukung oleh personalia (seperti administrator, guru, konselor, dan tata usaha yang bermutu dan professional), sarana dan prasarana pendidikan, fasilitas, media, sumber belajar yang memadai, biaya yang mencukupi, manajemen dan strategi yang tepat serta lingkungan yang medukung. Jika komponen berfungsi optimal akan menentukan terciptanya sekolah yang memiliki mutu lulusan yang unggul, yaitu mutu peserta didik yang mempunyai kemampuan dan keterampilan sesuai dengan tuntutan masyarakat.

Untuk mewujudkan tercapainya keberhasilan pendidikan di Sekolah, faktor lingkungan kerja tidak dapat diabaikan. Lingkungan kerja yang nyaman, dan keharmonisan kerja diantara teman sejawat akan sangat mendukung suasana kerja warga Sekolah, yang pada akhirnya akan mempunyai dampak positif terhadap keberhasilan pendidikan Sekolah tersebut. Tidak hanya hubungan baik antara sesama teman sekerja saja, yang diharapakan dapat tercipta, tetapi hubungan dan kerjasama yang baik dengan orang tua, masyarakat, dan pemerintah pun harus terpelihara dengan baik.

Untuk dapat menciptakan mutu pendidikan yang berkualitas, maka Sekolah harus memiliki budaya organisasi Sekolah yang efektif. Di dalam Sekolah terjadi interaksi yang saling mempengaruhi antara individu dengan lingkungannya, baik lingkungan fisik maupun sosial. Lingkungan ini akan dipersepsi dan dirasakan oleh individu tersebut sehingga menimbulkan kesan dan perasaan tertentu. Dalam hal ini, Sekolah harus dapat menciptakan suasana lingkungan kerja yang kondusif dan menyenangkan bagi setiap anggota Sekolah, melalui berbagai penataan lingkungan, baik fisik maupun sosialnya. Sekolah sebagai suatu organisasi, memiliki budaya tersendiri yang dibentuk dan dipengaruhi oleh nilai-nilai, persepsi, kebiasaankebiasaan, kebijakan-kebijakan pendidikan, dan perilaku orang-orang yang berada di dalamnya. 
Budaya Sekolah harus disadari oleh seluruh konstituen sebagai asumsi dasar dan kepercayaan yang dapat membuat Sekolah tersebut memiliki citra yang membanggakan stakeholders. Oleh karena itu, semua individu memiliki posisi yang sama untuk mengangkat citra melalui performance yang merujuk pada budaya Sekolah efektif.

Budaya Sekolah efektif merupakan nilai-nilai, kepercayaan, dan tindakan sebagai hasil kesepakatan bersama yang melahirkan komitmen seluruh personil untuk melaksanakannya secara konsekuen dan konsisten.

Budaya organisasi (Sekolah) bukan saja bermanfaat bagi anggota (Guru), tapi juga bagi organisasi (Sekolah) sebagai lembaga. Budaya organisasi bermanfaat sebagai salah satu unsur yang dapat menekan turn over pegawai (Guru) karena budaya organisasi (Sekolah) mendorong mereka (Guru) untuk konsisten dengan tugas dan tanggungjawabnya.

Pentingnya membangun budaya organisasi di Sekolah terutama berkenaan dengan upaya meningkatkan kinerja para Guru dan peningkatan mutu pendidikan di Sekolah dengan hasil lulusan yang berkualitas.

Selain dengan membangun dan mengembangkan budaya organisasi Sekolah guna meningkatkan mutu pendidikan di Sekolah, perhatian dan peningkatan motivasi kerja Guru juga perlu dilakukan. Guru akan termotivasi dalam berkerja jika ada faktor-faktor yang mendorong timbulnya semangat kerja yang menyentuh kebutuhan hidupnya. Seorang Guru yang melakukan aktivitas mengajar karena ada motivasi yang mendasarinya. Motivasi atau motivation berarti pemberian motif, penimbulan motive atau hal yang menimbulkan dorongan atau keadaan yang menimbulkan dorongan. Motivasi dapat pula diartikan faktor yang mendorong orang untuk bertindak dengan cara tertentu. Sedang motivasi kerja adalah dorongan yang menyebabkan seseorang Guru mau melakukan sesuatu kegiatan mengajar. Dorongan-dorongan itu bertujuan untuk menggiatkan Guru agar bersemangat dalam mengajar sehingga mencapai hasil sebagaimana dikehendaki sesuai tujuan. Bahwa jika kebutuhan Guru dapat terpenuhi dengan baik, maka akan mampu mendorong semangat kerja Guru tersebut sehingga kinerja menjadi meningkat dan pada akhirnya juga akan meningkatkan mutu pendidikan di Sekolah.

\section{TUJUAN PENELITIAN}

Penelitian ini akan menganalisa keterkaitan antara pengimplementasian budaya organisasi Sekolah dan pemenuhan motivasi kerja Guru terhadap peningkatkan mutu pendidikan, khususnya pada SD ISLAM TERPADU BAITUL JIHAD Kemang Pratama 2, Bekasi

\section{TELAAH LITERATUR DAN PENGEMBANGAN HIPOTESIS Budaya Organisasi Sekolah}

Dalam Kamus Besar Bahasa Indonesia (KBBI), kata "Budaya" diartikan sebagai pikiran, akal budi atau adat-istiadat. Secara tata bahasa, pengertian kebudayaan diturunkan dari kata budaya yang cenderung menunjuk pada pola pikir manusia. Kebudayaan sendiri diartikan sebagai segala hal yang berkaitan dengan akal atau pikiran manusia, sehingga dapat menunjuk pada pola pikir, perilaku serta karya fisik sekelompok manusia.

Bennett Silalahi (2014: 1) menyatakan bahwa : Kebudayaan adalah totalitas rangkaian adat istiadat turun-temurun yang mencakup perilakuan seni, kepercayaan, institusi dan kebiasaan terkait yang mengendalikan tata cara kehidupan suku bangsa. Kebudayaan juga mempengaruhi cara kerja petani ataupun pegawai organisasi. Karena keanekaragaman kebudayaan yang dibawa kedalam organisasi, maka manajemen organisasi perlu membentuk budaya khas organisasi secara tersendiri.

Menurut Schein dalam Wibowo (2010:15), menyatakan budaya adalah 
suatu pola asumsi dasar yang ditemukan dan dikembangkan oleh suatu kelompok tertentu karena mempelajari dan menguasai masalah adaptasi eksternal dan integrasi internal yang telah bekerja dengan cukup baik untuk dipertimbangkan secara layak dan karena itu diajarkan pada anggota baru sebagai cara yang dipersepsikan, berpikir, dan dirasakan dengan benar dalam hubungan dengan masalah tersebut.

Pengertian budaya organisasi menurut Wirawan (2007:10), adalah norma- norma, nilai-nilai, asumsi, kepercayaan, filsafat, kebiasaan organisasi, dan sebagainya yang dikembangkan dalam waktu yang lama oleh pendiri, pemimpin, dan anggota organisasi yang disosialisasikan dan diajarkan kepada anggota baru serta diterapkan dalam aktivitas organisasi sehingga mempengaruhi pola pikir, sikap, dan perilaku organisasi dalam memproduksi produk, melayani para konsumen, dan mencapai tujuan organisasi.

Jadi setiap organisasi Sekolah memiliki ciri khas yang dikenal sebagai budaya Sekolah. Ciri khas ini disebarluaskan di dalam Sekolah selama waktu yang tidak ditentukan dan diadopsi turun menurun. Budaya Sekolah atau budaya organisasi Sekolah saat ini menduduki peran yang sangat penting dalam perkembangan Sekolah, seiring bergesernya paradigma pemanfaatan budaya Sekolah. Dahulu budaya Sekolah hanya sebagai sarana pengukuhan jati diri yang dilandasi oleh penggalian nilai-nilai mengapa Sekolah mencapai sukses kini telah bergeser ke arah pemanfaatan budaya Sekolah secara nyata sebagai alat untuk mencapai tujuan dengan mempertanyakan nilai-nilai seperti apa yang dibutuhkan Sekolah agar senantiasa kompetitif.

Budaya Sekolah harus disadari oleh seluruh konstituen sebagai asumsi dasar dan kepercayaan yang dapat membuat Sekolah tersebut memiliki citra yang membanggakan stakeholders. Oleh karena itu, semua individu memiliki posisi yang sama untuk mengangkat citra melalui performance yang merujuk pada budaya Sekolah efektif. Budaya Sekolah efektif merupakan nilai-nilai, kepercayaan, dan tindakan sebagai hasil kesepakatan bersama yang melahirkan komitmen seluruh personnel untuk melaksanakannya secara konsekuen dan konsisten.

Maka dapat disimpulkan bahwa budaya Sekolah adalah sebagai karakteristik khas Sekolah yang dapat diidentifikasikan melalui nilai yang dianutnya, sikap yang dimilikinya, kebiasaan-kebiasaan yang ditampilkannya, dan tindakan yang ditunjukkan oleh seluruh personnel Sekolah yang membentuk satu kesatuan khusus dari sistem Sekolah.

Penerapan budaya organisasi sangat ditentukan oleh pimpinan organisasi. Pimpinan harus memiliki komitmen kuat menerapkan budaya organisasi, setelah itu baru dapat diinternalisasi kepada para personil. Mengembangkan, melanjutkan, dan mempertahankan budaya organisas Sekolah adalah kewajiban setiap anggota masyarakat Sekolah. Namun Kepala Sekolah punya peran terpenting dalam peningkatan budaya organisasi Sekolah. Lingkungan Sekolah sebagai lembaga layanan pendidikan dipengaruhi faktor internal dan eksternal. Karena itu, Kepala Sekolah sebagai manajer pendidikan dituntut mampu memberdayakan seluruh potensi Sekolah. Kepala Sekolah mempunyai peran paling penting untuk mengembangkan budaya organisasi Sekolah ke arah budaya yang kuat dan positif.

Budaya dalam organisasi sekolah, lebih ditekankan pada terjaganya nilainilai utama kehidupan yang dilandasi keimanan dan ketakwaan kepada Pencipta. Hal ini dapat dilakukan dengan cara memelihara kebiasaankebiasaan produktif dalam menelaah ilmu dan melaksanakan kinerja keilmuan tanpa mengabaikan lingkungan sosial tempat berinteraksi dan mengekspresikan kreativitas produktif manusia.

Pucuk pimpinan di Sekolah bukan seperti di Sekolah yang menekankan 
kepada untung-rugi suatu usaha. Walaupun demikian, Sekolah tetap memperhitungkan segi benefit (kebermanfaatan suatu usaha), hal ini berimplikasi pada profit kepala sekolah yang lebih sebagai pemimpin yang memiliki amanah menciptakan budaya positif yang relevan dengan produktivitas sekolah, bukan sebagai penguasa yang dapat memaksakan otoritasnya. Sekolah sebagai sistem terbuka, senantiasa menerima pengaruh dari luar dan harus terus beradaptasi, bahkan memberi warna kepada perubahan lingkungan. Keberadaan budaya organisasi dalam sekolah terkait dengan dimensi-dimensi lainnya, yaitu milieu, ekologi, struktur organisasi yang secara bersama-sama membentuk apa yang disebut dengan iklim sekolah.

Budaya organisasi muncul dalam dua tingkatan, yaitu tingkatan yang kurang terlihat, berupa nilai-nilai yang dianut oleh anggota kelompok yang cenderung bertahan meskipun anggotanya sudah ganti. Nilai-nilai ini sangat sukar berubah dan anggota organisasi seringkali tidak menyadari karena banyaknya nilai. Tingkatan yang lebih terlihat berupa pola gaya perilaku organisasi, yakni orang-orang yang baru masuk terdorong untuk mengikutinya.

Sekolah sebagai suatu bentuk organisasi memiliki budaya tersendiri yang membentuk corak dari sistem yang utuh dan khas. Kekhasan budaya sekolah tidak terlepas dari visi dan proses pendidikan yang berlangsung yang menuntut keberadaan unsurunsur atau komponen-komponen sekolah sebagai bidang garapan organisasi. Unsur-unsur tersebut satu sama lain berinteraksi dan secara resiprokal memiliki kaitan satu sama lain, baik yang bersifat artifact maupun nilai-nilai, dalam organisasi itu sendiri maupun dengan lingkungan eksternal.

Unsur-unsur budaya organisasi yang dimaksud di atas adalah sebagai berikut:

Lingkungan Usaha; organisasi memiliki lingkungan usaha sendiri, dan dalam praktiknya harus memerhatikan customer, teknologi, persaingan, mutu, stakeholders, dan faktor lainnya mendukung keberhasilan usaha.

Nilai-nilai (Values); nilai merupakan idealisasi cita-cita seseorang. Sebagai cita-cita tentu sangat didambakan, diharapkan, dan diinginkan perwujudannya. Nilai organisasi harus dijunjung tinggi setiap anggotanya karena akan menentukan perilaku yang ditampilkannya. Macam-macam nilai ini misalnya nilai kejujuran, nilai kemandirian, nilai pemberdayaan, nilai keikhlasan, nilai ibadah, dan sebagainya.

Keteladanan/Kepahlawanan;

keberadaan organisasi tidak lepas dari filsafat dan tujuan para pendirinya. Para pendiri dan pemimpin organisasi memiliki peran besar yang turut menentukan, membentuk, dan menanamkan nilai-nilai budaya yang akan dijadikan rujukan setiap anggotanya. Para pendiri dan pemimpin organisasi berkewajiban mensosialisasikan nilai-nilai tersebut kepada seluruh anggota, sekaligus menjadi suri teladan dalam sikap dan tindakannya.

Upacara / Tata Cara; upacaraupacara dalam organisasi merupakan kewajaran adanya, namun upacara yang khas yang mencerminkan budaya organisasi dapat dibentuk dalam rangka menumbuhkan kedisiplinan ataupun dalam mengekspresikan rasa syukur atas keberhasilan atau untuk menumbuhkan kebanggaan setiap anggota terhadap organisasinya. Upacara-upacara dapat dilakukan untuk memperingati hari-hari besar keagamaan, keberhasilan anggota dalam meraih prestasi, atau untuk mensiasati

kebersamaan/silaturahmi informal.

Jaringan (Network); pada saat sekarang, keberadaan jaringan dapat menentukan keberhasilan. Jaringan dibentuk untuk memperkokoh keberadaan organisasi, juga untuk memperlancar berbagai usaha. 
Melalui pembentukan jaringan, perekayasaan usaha yang dikemas dalam saluran komunikasi yang solid dapat mempermudah, memperlancar, mensosialisasikan, memperkokoh memperluas, dan organisasi.

\section{Motivasi Kerja}

Motivasi merupakan salah satu aspek yang sangat penting dalam menemukan perilaku seseorang, termasuk perilaku kerja. Untuk dapat memotivasi seseorang diperlukan pemahaman tentang bagaimana proses terbentuknya motivasi. Motivasi harus datang dari diri sendiri, bersifat individual, sengaja dan bersegi banyak.

Motivasi bersifat individual dalam arti bahwa setiap orang termotivasi oleh berbagai pengaruh hingga berbagai tingkat. Motivasi bersifat sengaja karena individu mengendalikan tingkat motivasinya sendiri. Sifat individual dari motivasi menuntut para pemimpin organisasi untuk melalui suasana organisasi yang mendorong para Pegawai untuk lebih produktif.

Menurut Handoko (2012: 252) motivasi adalah "Keadaan dalam pribadi seseorang yang mendorong keinginan individu untuk melakukan kegiatankegiatan tertentu guna mencapai tujuan". Menurut Hasibuan yang dikutip oleh Edy Sutrisno (2009: 117) mengatakan bahwa motivasi adalah: "Pemberian daya penggerak yang menciptakan kegairaan kerja seseorang, agar mereka mau bekerjasama, bekerja efektif dan terintegrasi dengan segala daya upaya untuk mencapai kepuasan". Selanjutnya menurut Robbins yang dikutip oleh Edy Sutrisno (2009: 117) menyatakan motivasi ialah "Suatu kerelaan berusaha seoptimal mungkin dalam pencapaiaan tujuan organisasi yang dipengaruhi oleh kemampuan usaha memuaskan beberapa kebutuhan individu".

Motivasi menurut Robbins, (dikutip oleh Winardi, 2002: 1) menyatakan bahwa motivasi adalah "Kesediaan untuk melaksanakan upaya tinggi untuk mencapai tujuan-tujuan keorganisasian, yang dikondisikan oleh kemampuan upaya untuk memenuhi kebutuhan individual tertentu". Selanjutnya dikatakan bahwa: "motivasi adalah suatu kekuatan potensial yang ada dalam diri manusia, yang dapat dikembangkan sendiri, atau dikembangkan oleh sejumlah kekuatan luar pada intinya berkisar sekitar imbalan moneter dan imbalan non moneter yang dapat mempengaruhi hasil kinerjanya secara positif atau secara negatif, hal mana tergantung pada situasi dan kondisi yang dihadapi orang yang bersangkutan".

Dari berbagai definisi yang dikemukakan di atas, dapat diambil kesimpulan bahwa yang dimaksud dengan motivasi kerja adalah sebagai penguat atau kekuatan untuk mendorong seseorang dalam mencapai tujuan dan hasil suatu pekerjaan secara optimal.

Dalam proses pembelajaran, motivasi merupakan salah satu faktor yang mempengaruhi proses dan hasil belajar. Motivasi juga merupakan faktor yang memprakarsai, memperkuat, dan mempertahankan perilaku. Di samping itu motivasi juga untuk menggerakkan, mengarahkan, dan mempertahankan perilaku.

Dengan demikian secara singkat dapat diambil kesimpulan bahwa salah satu tugas utama pemimpin adalah menumbuhkan motivasi para Guru untuk terdorong melakukan pekerjaan secara produktif. Untuk itu pemimpin harus dapat menempuh cara-cara sebagai berikut :

- Merubah kondisi yang kurang kondusif menjadi kondisi yang kondusif.

- Menggunakan teknik-teknik manajemen mempengaruhi bawahan untuk berkerja produktif.

Fungsi motivasi bagi tenaga kependidikan memperlihatkan bahwa proses kegiatan belajar mengajar akan berjalan lancar dan berhasil dengan baik apabila pada gurunya tumbuh motivasi untuk meningkatkan kualitas lulusan dalam melaksanakan pekerjaannya, serta hubungan antara individu baik hubungan antara guru dengan kepala, 
hubungan antara guru dengan guru, maupun hubungan antara guru dengan siswa terjalin hubungan yang hannonis. Untuk itu agar para guru tumbuh motivasi dalam melaksanakan tugasnya sesuai dengan yang diharapkan, maka seorang pemimpin harus mampu mengerti tentang kondisi para gurunya karena guru tersebut sebagai sumber daya yang perlu terus diarahkan dan dibina.

Kepala Sekolah harus mampu menumbuhkan motivasi, terutama motivasi para guru untuk bertindak dan melakukan kerja. Motivasi seseorang dipengaruhi oleh banyaknya faktor yang dapat dikelompokkan dalam tiga golongan, yaitu :

Latar belakang dan Pengalaman.

Sikap Pribadi.

Harapan, Keinginan dan Ambisi.

Motivasi sebagai inti kepemimpinan adalah bagaimana menimbulkan dorongan kerja seseorang dengan memahami latar belakang dan pengalamannya. Mengerti sikap pribadinya, serta mencoba mengenal apa yang menjadi harapannya, keinginannya dan ambisinya, baik di lingkungan kerja maupun di luar lingkungan kerja.

Ada banyak faktor yang dapat mempengaruhi atau berdampak pada tingkat motivasi seseorang, diantaranya adalah sebagai berikut: Jenis Penghasilan; Pemenuhan kebutuhan; Faktor kepuasan kerja; Dukungan pimpinan; Kesesuaian pekerjaan; Dukungan luar; Penghargaan prestasi; Kemampuan; Pengawasan; Keamanan / Keselamatan; Keindahan; Kenyamanan; Ketentraman; Ketertiban.

Sekolah merupakan organisasi yang terdiri kumpulan orang-orang yang berkerja sama untuk mencapai tujuan yang telah ditentukan. Agar kerjasama dapat berjalan baik maka semua unsur dalam organisasi terutama sumber daya manusia harus dapat terlibat secara aktif dan memiliki dorongan untuk bersama-sama mencapi tujuan. Pimpinan dalam hal ini berperanan penting untuk menggerakkan bawahan termasuk juga dirinya sendiri.
Agar sumber daya manusia dapat digerakkan dalam rangka mencapai tujuan organisasi maka perlu dipahami motivasi mereka dalam berkerja terutama untuk para guru adalah penekanan pada motivasi kerja mereka. Pemberian motivasi kepala sekolah kepada guru maupun motivasi yang timbul dari diri guru sendiri untuk berkerja sambil berprestasi akan mampu mencapai kepuasan kerjanya, tercapainya kinerja organisasi yang maksimal dan tercapainya tujuan organisasi.

\section{Mutu Pendidikan}

Mutu dapat diartikan sebagai sesuatu yang sesuai dengan yang dipersyaratkan atau distandarkan. Untuk itu, mutu pendidikan seringkali diukur dengan Standar Mutu Layanan Pendidikan. Menurut PP No. 19 tahun 2005 pasal 2 bahwa penyelenggaraan Pendidikan Nasional harus memenuhi standar-standar sebagai berikut.:

Standar Isi. Meliputi ruang lingkup materi dan kompetensi: Kompetensi tamatan, kompetensi materi, kompetensi bahan kajian, kurikulum dan silabus pembelajaran.

Standar Proses. Berkaitan dengan pelaksanaaan PBM untuk mencapai standar kompetensi lulusan. Proses pembelajaran tersebut diselenggarakan secara interaktif, inspiratif, menyenangkan, menantang, memotivasi, partisipatif, kreatrif dan mandiri sesuai dengan perkembangan peserta didik. Proses pembelajaran harus dilaksanakan secara efektif dan efisien.

Standar Kompetensi Lulusan. Kualifikasi kemampuan lulusan yang meliputi sikap, pengetahuan, dan keterampilan.

Standar Pendidik dan Tenaga Kependidikan. Meliputi kriteria pendidikan prajabatan, kelayakan fisik maupun mental dan pendidik dalam jabatan. Kompetensi agen pembelajaran yang harus dimiliki seorang pendidik adalah: (a). Kompetensi Pedagogik; (b). Kompetensi Kepribadian; (c). 
Kompetensi Profesional; dan (d). Kompetensi Sosial.

- Standar Sarana dan Prasarana. Berkaitan dengan kriteria minimal ruang belajar, tempat beribadah, tempat olah raga, laboratorium, bengkel kerja, tempat bermain, sumber dan media belajar dan alat bantu lain yang diperlukan dalam proses pembelajaran.

- Standar Pengelolaan. Berkaitan dengan perencanaan, pelaksanaan, dan pengawasan kegiatan pendidikan.

- Standar Pembiayaan. Menyakut komponen dan biaya operasi satuan pendidikan, seperti biaya investasi, biaya operasi dan biaya personal.

\section{Standar Penilaian Pendidikan.} Berkaitan dengan mekanisme, prosedur, dan instrumen penilaian hasil belajar. Penilaian oleh pendidik, penilaian oleh satuan pendidikan, dan penilaian oleh pemerintah.

Secara umum kualitas atau mutu adalah gambaran dan karakteristik menyeluruh dari barang atau jasa yang menunjukkan kemampuannya dalam memuaskan kebutuhan yang diharapkan atau tersirat (Depdiknas, 2002: 7).

Mutu pendidikan dapat dilihat dalam dua hal, yakni mengacu pada proses pendidikan dan hasil pendidikan. Proses pendidikan yang bermutu apabila seluruh komponen pendidikan terlibat dalam proses pendidikan itu sendiri. Faktor-faktor dalam proses pendidikan adalah berbagai input, seperti bahan ajar, metodologi, sarana sekolah, dukungan administrasi dan sarana prasarana dan sumber daya lainnya serta penciptaan suasana yang kondusif. Sedangkan mutu pendidikan dalam konteks hasil pendidikan mengacu pada prestasi yang dicapai oleh sekolah pada setiap kurun waktu tertentu. Prestasi yang dicapai atau hasil pendidikan (student achievement) dapat berupa hasil tes kemampuan akademis (misalnya ulangan umum, Ebta dan Ebtanas). Dapat pula di bidang lain seperti prestasi di suatu cabang olahraga, seni atau keterampilan tambahan tertentu misalnya computer, beragam jenis teknik, jasa dan sebagainya. Bahkan prestasi sekolah dapat berupa kondisi yang tidak dapat dipegang (intangible) seperti suasana, disiplin, keakraban, saling menghormati, kebersihan, dan sebagainya (Suryosubroto, 2004: 210-211).

UU RI No. 20 Tahun 2003, tentang SISDIKNAS melihat pendidikan dari segi proses dengan dengan merumuskan pendidikan sebagai usaha sadar dan terencana untuk mewujudkan suasana belajar dan proses pembelajaran agar peserta didik secara aktif mengembangkan potensi dirinya untuk memiliki kekuatan spiritual keagamaan, pengendalian diri, kepribadian, kecerdasan, akhlak mulia, serta keterampilan yang diperlukan dirinya, masyarakat, bangsa dan Negara. (Fokusmedia, 2003: 3).

Terdapat tiga faktor yang dapat menyebabkan rendahnya mutu pendidikan, yaitu : (1). Kebijakan dan penyelenggaraan pendidikan nasional menggunakan pendekatan educational production function atau input-input analisis yang tidak konsisten; (2). penyelenggaraan pendidikan dilakukan secara sentralistik; (3). peran serta masyarakat khususnya orang tua siswa dalam penyelenggaraan pendidikan sangat minim.

Berdasarkan penyebab tersebut dan dengan adanya era otonomi daerah yang sedang berjalan maka kebijakan strategis yang diambil Direktorat Jenderal Pendidikan Dasar dan Menengah dalam meningkatkan mutu pendidikan untuk mengembangkan SDM adalah : (1) Manajemen peningkatan mutu berbasis sekolah (school based management) dimana sekolah diberikan kewenangan untuk merencanakan sendiri upaya peningkatan mutu secara keseluruhan; (2) Pendidikan yang berbasiskan pada partisipasi komunitas (community based education) dimana terjadi interaksi yang positif antara sekolah dengan masyarakat, sekolah sebagai community learning center; dan (3) Dengan menggunakan paradigma belajar atau learning paradigm yang akan 
menjadikan pelajar-pelajar atau learner menjadi manusia yang diberdayakan. Selain itu pada tanggal 2 Mei 2002, bertepatan hari pendidikan nasional, pemerintah telah mengumumkan suatu gerakan nasional untuk peningkatan mutu pendidikan, sekaligus menghantar perluasan pendekatan Broad Base Education System (BBE) yang memberi pembekalan kepada pelajar untuk siap berkerja membangun keluarga sejahtera. Dengan pendekatan itu setiap siswa diharapkan akan mendapatkan pembekalan life skills yang berisi pemahaman yang luas dan mendalam tentang lingkungan dan kemampuannya agar akrab dan saling memberi manfaat. Lingkungan sekitarnya dapat memperoleh masukan baru dari insan yang mencintainya, dan lingkungannya dapat memberikan topangan hidup yang mengantarkan manusia yang mencintainya menikmati kesejahteraan.

Untuk merealisasikan kebijakan di atas maka Sekolah perlu melakukan manajemen peningkatan mutu. Manajemen peningkatan mutu sekolah adalah suatu metode peningkatan mutu yang bertumpu pada sekolah itu sendiri, mengaplikasikan sekumpulan teknik, mendasarkan pada ketersediaan data kuantitatif \& kualitatif, dan pemberdayaan semua komponen sekolah untuk secara berkesinambungan meningkatkan kapasitas dan kemampuan organisasi sekolah guna memenuhi kebutuhan peserta didik dan masyarakat. Dalam Manajemen Peningkatan Mutu (MPM) terkandung upaya :

- Mengendalikan proses yang berlangsung di sekolah baik kurikuler maupun administrasi,

- Melibatkan proses diagnosa dan proses tindakan untuk menindak lanjuti diagnosa,

- Memerlukan partisipasi semua fihak : Kepala Sekolah, guru, staf administrasi, siswa, orang tua dan pakar.

Konsep pengelolaan peningkatan Mutu Pendidikan haruslah menawarkan kerjasama yang erat antara sekolah, masyarakat, dan pemerintah dengan tangung jawabnya masing-masing, berkembang didasarkan pada keinginan memberikan kemandirian kepada sekolah untuk ikut terlibat secara aktif dan dinamis dalam rangka proses peningkatan kualitas pendidikan melalui pengelolaan sumber daya sekolah yang ada. Untuk itu sekolah harus mampu menterjemahkan dan menangkap esensi kebijakan makro pendidikan serta memahami kondisi lingkungannya (kelebihan dan kekurangannya) untuk kemudian melalui proses perencanaan, sekolah harus memformulasikannya ke dalam kebijakan mikro dalam bentuk program-program prioritas yang harus dilaksanakan dan dievaluasi oleh sekolah sesuai dengan visi dan misinya masing-masing. Sekolah harus menentukan target mutu (dalam arti luas) yang ingin dicapai untuk setiap kurun waktu, merencanakannya, melaksanakan dan evaluasi dirinya, untuk kemudian menetukan target mutu untuk tahun berikutnya. Dengan demikian sekolah dapat mandiri tetapi masih dalam rangka acuan kebijakan nasional, dan bertanggung jawab (memiliki akuntabilitas) terhadap kebutuhan belajar siswa dan masyarakat.

Berbagai indikator yang menunjukkan karakter dari konsep manajemen peningkatan mutu sekolah, antara lain :

- $\quad$ Lingkungan sekolah yang aman dan tertib.

Sekolah memiliki visi dan target mutu yang ingin dicapai.

Sekolah memiliki kepemimpinan yang kuat.

- Adanya harapan yang tinggi dari personel sekolah (Kepala Sekolah, guru, dan staf lainnya termasuk siswa) untuk berprestasi.

- Adanya pelaksanaan evaluasi yang terus menerus terhadap berbagai aspek akademik dan administratif, dan pemanfaatan hasilnya untuk penyempurnaan/perbaikan mutu.

- Adanya pengembangan staf sekolah yang terus menerus sesuai tuntutan IPTEK.

- Adanya komunikasi dan dukungan insentif dan orang tua murid/masyarakat. 
Berikut ini adalah beberapa karakteristik utama dari sekolah yang efektif, antara lain :

Mempunyai cukup otonomi yang memungkinkan seluruh pegawai terlibat dalam perencanaan, kerjasama dan kolaborasi antar guru.

- Kepemimpinan yang memungkinkan pegawai ada semua tingkat untuk mengambil inisiatif pengembangan proses kerja yang efisien dengan produktivitas tinggi.

- Mengikutsertakan seluruh staf dalam mengembangkan proses dan sistem serta suasana kerja di sekolah, sehingga staf tersebut betah berkerja dan merasa serta bertanggung jawab terhadap keberhasilan sekolah.

- Kurikulum berdasarkan pada, dan mendukung, tujuan-tujuan harapan-harapan sekolah. Perencanaan dan pengorganisasian yang baik akan membantu penyediaan kurikulum yang sesuai dengan tujuan sekolah, sekaligus juga untuk pengembangannya.

- Memperhatikan pengembangan staf, terutama dengan mengikutsertakan pegawai dalam perancangan tujuan dalam bentuk tim kerja.

- Memaksimalkan waktu belajar dalam kelas secara bijaksana dan mengurangi berbagai akibat negatif dari kegiatan belajar di kelas.

- Menyebarluaskan semangat sukses akademik. Untuk itu penguatan yang bersifat positif dalam kerangka kerjasama tim sangat diperlukan untuk meningkatkan semangat kerja (morale) dalam mencapai standar akademik tertentu.

- Dukungan dan keterlibatan orang tua dalam penyelenggaraan pendidikan.

\section{Kerangka Konseptual}

Guna meningkatkan mutu pendidikan di Sekolah, Budaya dalam organisasi sekolah, lebih ditekankan pada terjaganya nilai-nilai utama kehidupan yang dilandasi keimanan dan ketakwaan kepada Pencipta. Hal ini dapat dilakukan dengan cara memelihara kebiasaan-kebiasaan produktif dalam menelaah ilmu dan melaksanakan kinerja keilmuan tanpa mengabaikan lingkungan sosial tempat berinteraksi dan mengekspresikan kreativitas produktif manusia. Selain itu perhatian dan peningkatan motivasi kerja Guru juga perlu dilakukan. Guru akan termotivasi dalam berkerja jika ada faktor-faktor yang mendorong timbulnya semangat kerja yang menyentuh kebutuhan hidupnya.

Dalam penelitian ini meliputi dua variabel bebas yaitu variabel X1 (Budaya Organisasi Sekolah) dan variabel X2 (Motivasi Kerja Guru). Dan satu variabel terikat yaitu variabel Y (Mutu Pendidikan). Model hubungan antara variabel bebas dengan variabel terikat dalam penelitian ini dapat lihat pada gambar berikut:

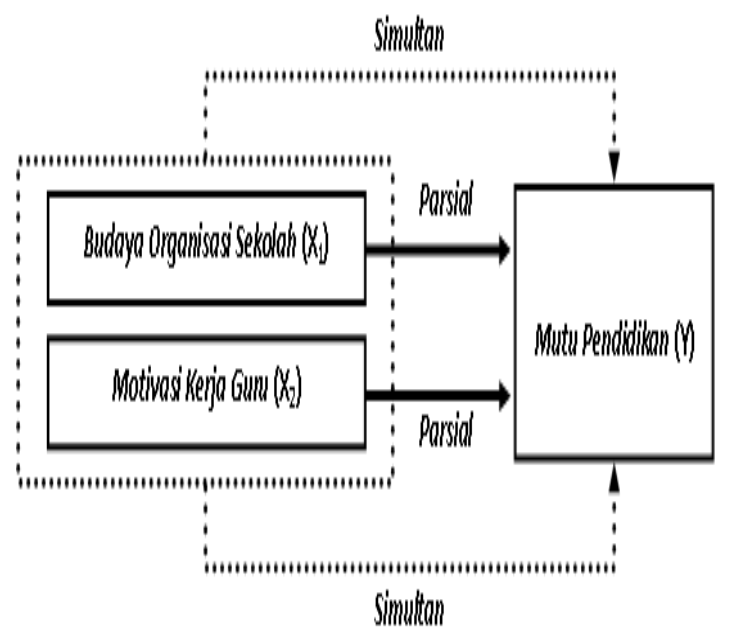

\section{METODE PENELITIAN Jenis Penelitian}

Jenis dan rancang penelitian dapat dikelompokkan sesuai tujuan penelitian, pendekatan, tingkat eksplanasi dan jenis data. Penelitian ini tergolong penelitian asosiatif yaitu penelitian yang bersifat mencari hubungan atau pengaruh antara satu variabel dengan variabel lainnya.

\section{Lokasi dan Waktu Penelitian}

Adapun lokasi yang dipilih sebagai tempat penelitian SD ISLAM TERPADU BAITUL JIHAD KEMANG PRATAMA 2, BEKASI, Jl. Kemang dahlia raya, 
Kemang Pratama 2, Bekasi. Waktu penelitian dilaksanakan pada bulan Maret sampai dengan bulan Juni 2018.

\section{Populasi dan Sampel Penelitian}

Penentuan sumber data bergantung pada masalah yang akan diteliti, serta hipotesis yang akan diuji kebenarannya. Pada penelitian ini yang menjadi populasi penelitian adalah para Guru SD ISLAM TERPADU BAITUL JIHAD KEMANG PRATAMA 2, BEKASI, yaitu sebanyak 42 orang Guru. Dikarenakan jumlah populasi (Guru) adalah kurang dari 100, maka seluruh populasi dijadikan sebagai sampel penelitian. Jadi jumlah sampel (responden) dalam penelitian ini adalah sebanyak 42 orang Guru pada SD ISLAM TERPADU BAITUL JIHAD KEMANG PRATAMA 2, BEKASI.

\section{Variabel Penelitian}

Dalam penelitian ini : Variabel bebas adalah Budaya Organisasi Sekolah (X1) dan Motivasi Kerja Guru (X2) . Variabel terikat adalah Mutu Pendidikan ( Y).

1. Indikator Budaya Organisasi Sekolah (X1) :

- $\quad$ Lingkungan Organisasi Sekolah.

- Nilai-nilai.

- Keteladanan.

- Tata Cara.

- Jaringan.

2. Indikator Motivasi Kerja Guru (X2) :

- Jenis Penghasilan.

- Pemenuhan kebutuhan.

- Faktor kepuasan kerja.

- Dukungan pimpinan.

- Kesesuaian pekerjaan.

- Dukungan luar.

- Penghargaan prestasi.

- Kemampuan.

- Pengawasan.

- Keamanan / Keselamatan.

- Keindahan.

- Kenyamanan.

- Ketentraman.

- Ketertiban.

3. Indikator Mutu Pendidikan (X1) :

- Lingkungan Sekolah yang aman dan tertib.

- Sekolah memiliki visi dan target mutu yang ingin dicapai.
- Sekolah memiliki kepemimpinan yang kuat.

- Adanya harapan yang tinggi dari personel Sekolah (Kepala Sekolah, Guru, dan staf lainnya termasuk siswa) untuk berprestasi.

- Adanya pengembangan Guru dan staf Sekolah yang terus menerus sesuai tuntutan IPTEK.

- Adanya pelaksanaan evaluasi yang terus menerus terhadap berbagai aspek akademik dan administratif, dan pemanfaatan hasilnya penyempurnaan/perbaikan mutu.

- Adanya komunikasi dan dukungan insentif dan orang tua murid/masyarakat.

\section{Prosedur Pengumpulan Data}

Penelitian ini penulis mengumpulkan data yang berhubungan dengan masalah yang sedang diteliti, adapun teknik yang digunakan yaitu sebagai berikut :

Penelitian Kepustakaan Penelitian yang dilakukan dengan cara membaca dan mempelajari literatur yang terdapat di perpustakaan, dengan maksud untuk menempatkan landasan teoritis mengenai masalah pokok yang sedang dibahas.

Penelitian Lapangan

Penelitian terhadap objek yang diteliti dan pencarian data pada objek penelitian dengan cara observasi, wawancara. penyebaran angket dan kuisioner

Data diperoleh dari hasil daftar pertanyaan (kuisioner) yang telah dijawab dan diserahkan kembali oleh 42 responden sebagai sampel dalam penelitian ini. Pada proses penelitian memerlukan suatu analisis untuk memperoleh kebenaran data. Hasil analisis tersebut dapat ditafsirkan untuk menjawab suatu pemasalahan yang telah dirumuskan, berdasarkan teknik analisis yang telah ditentukan dan sesuai dengan 
pemasalah yang akan dikaji. Analisis data merupakan langkah kritis dalam sebuah penelitian, berdasar proses penarikan sampel dan pengumpulan data akan diperoleh data kasar, langkah selanjutnya adalah menginterpretasi data-data tersebut agar dapat ditarik suatu hasil penelitian, dimana hal ini membutuhkan suatu metode. Metode statistik merupakan cara untuk memperoleh data dan menarik kesimpulan-kesimpulan yang logis dari pengolahan data.

\section{Uji Validitas dan Realibilitas}

Kualitas data penelitian sangat tergantung pada kualitas data yang dipakai didalam penelitian. Kualitas data penelitian ditentukan oleh instrumen yang digunakan untuk mengumpulkan data untuk menghasilkan data yang berkualitas. Instrumen penelitian yang baik harus memenuhi persyaratan yaitu valid dan reliabel. Untuk mengetahui validitas dan reliabilitas kuisioner perlu dilakukan pengujian atas kuisioner dengan menggunakan uji validitas dan uji reliabilitas.

\section{Analisa Regresi Berganda}

Persamaan analisa regresi berganda (dua prediktor) yang digunakan adalah sebagai berikut: $\mathrm{Y}=\mathrm{a}+\mathrm{b} 1 \mathrm{X} 1+$ b2X2.

\section{HASIL PENELITIAN DAN PEMBAHASAN Hasil uji validitas}

Suatu data dapat dikatakan valid apabila nilai korelasi (r) hitung data tersebut melebihi nilai korelasi (r) tabelnya. Nilai $r$ hitung adalah nilai-nilai yang berada dalam kolom "Corrected Item Total Correlation" dan nilai korelasi tabel yang diperoleh dari hasil perhitungan $(\mathrm{Df}=\mathrm{N}-2$ dan $=5 \%)$ adalah sebesar 0.3044. Jika $r$ hasil positif, dan $r$ hitung $>r$ tabel, maka butir pertanyaan atau variabel tersebut valid.

Berdasarkan hasil uji validitas 60 item pertanyaan tersebut di atas, ternyata semua instrumen penelitian menunjukkan angka lebih besar dari $r$ tabel. Hal ini menunjukkan bahwa alat ukur yang digunakan telah valid dan dapat digunakan sebagai indikator dalam penelitian ini.

\section{Uji Reliabilitas}

Hasil uji reliabilitas yang disajikan pada tabel di atas menunjukkan bahwa alat ukur yang digunakan 100\% reliabel $(\alpha>0,6)$ yaitu variabel X1 (Budaya Organisasi Sekolah) sebesar 0,945, variabel X2 (Motivasi Kerja Guru) sebesar 0,936, dan variabel Y (Mutu Pendidikan) sebesar 0,941. Hal ini menunjukkan bahwa semua variabel bebas dan variabel terikat dapat dinyatakan reliabel.

\section{Koefisien Korelasi Berganda \\ .. Lodel Summary $^{b}$}

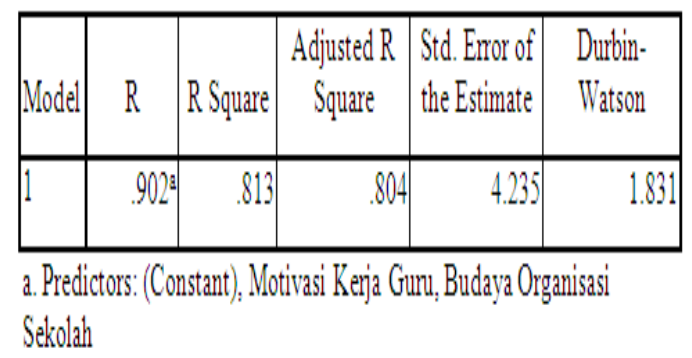

\section{b. Dependent Variable: Mutu Pendidikan}

Sumber : Data diolah

Berdasarkan tabel di atas ditemukan bahwa hubungan antara Budaya Organisasi Sekolah dan Motivasi Kerja Guru secara bersama-sama terhadap Mutu Pendidikan di SD ISLAM TERPADU BAITUL JIHAD KEMANG PRATAMA 2, BEKASI adalah positif dan sangat kuat, yaitu sebesar 0,902.

\section{Uji Hipotesa}

Dengan taraf kesalahan, yaitu : $5 \%$ dan $\mathrm{Df}=\mathrm{n}-\mathrm{m}-1=39$, kemudian diperoleh Ftabel $=3,2381$, berarti $\mathrm{F}$ hitung jatuh pada daerah penolakan Ho3, maka Ha3 diterima. Jadi kesimpulannya adalah koefisien korelasi antara faktor Budaya Organisasi Sekolah dan Motivasi Kerja Guru secara bersama-sama terhadap Mutu 
Pendidikan di SD ISLAM TERPADU BAITUL JIHAD KEMANG PRATAMA 2, BEKASI adalah signifikan.

\section{Analisa Regresi Berganda}

Analisa regresi linier berganda digunakan untuk mengetahui pengaruh variabel bebas (X1) dan (X2) terhadap variabel terikat $(\mathrm{Y})$. Adapun persamaan regresi yang digunakan dalam penelitian ini adalah: $\mathrm{Y}=\mathrm{a}+\mathrm{b} 1 \mathrm{X} 1+\mathrm{b} 2 \mathrm{X} 2$.

Hasil perhitungan regresi linier berganda dengan bantuan program SPSS adalah sebagai berikut: verikul:

Coefficients $^{a}$

\begin{tabular}{|l|r|r|r|r|r|}
\hline \multirow{2}{*}{ Model } & \multicolumn{2}{|c|}{$\begin{array}{l}\text { Unstandardized } \\
\text { Coefficients }\end{array}$} & $\begin{array}{r}\text { Standardized } \\
\text { Coefficients }\end{array}$ & & \\
\cline { 2 - 4 } & \multicolumn{1}{|c|}{ B } & Std. Error & \multicolumn{1}{|c|}{ Beta } & \multicolumn{1}{c|}{$\mathrm{t}$} & \multicolumn{1}{c|}{ Sig. } \\
\hline $1 \quad$ (Constant) & 13.191 & 6.100 & & 2.162 & .037 \\
$\begin{array}{l}\text { Budaya Organisasi } \\
\text { Sekolah }\end{array}$ & .314 & .084 & .408 & 3.732 & .001 \\
& 1.552 & .110 & .548 & 5.007 & .000 \\
\hline
\end{tabular}

a. Dependent Variable: Mutu Pendidikan

Sumber: Data diolah menggunakan program SPSS

Berdasarkan hasil analisa regresi di atas, maka dapat disusun persamaan regresi, yaitu: $\mathrm{Y}=13,191+0,314 \mathrm{X} 1+$ $1,552 \mathrm{X} 2$. Kemudian interpretasi dari persamaan tersebut adalah sebagai berikut:

Konstanta (a $=13,191)$, artinya angka ini menunjukkan kualitas Mutu Pendidikan, yaitu pada saat SD ISLAM TERPADU BAITUL JIHAD KEMANG PRATAMA 2, BEKASI tidak sama sekali memiliki kualitas Budaya Organisasi Sekolah yang baik dan juga para Guru SD ISLAM TERPADU BAITUL JIHAD KEMANG PRATAMA 2, BEKASI tidak memiliki kualitas Motivasi Kerja Guru yang baik sama sekali.

Koefisien regresi $(\mathrm{b} 1=0,314)$, artinya jika kualitas Budaya Organisasi Sekolah yang terjadi bertambah sebesar satu kali maka kualitas Mutu Pendidikan di SD ISLAM TERPADU BAITUL JIHAD KEMANG PRATAMA 2, BEKASI akan bertambah sebesar 0,314 kali.
- Koefisien regresi (b2 = 1,552), artinya jika tingkat kualitas Motivasi Kerja Guru yang terjadi bertambah sebesar satu kali maka kualitas Mutu Pendidikan di SD ISLAM TERPADU BAITUL JIHAD KEMANG PRATAMA 2, BEKASI akan bertambah sebesar 1,552 kali.

\section{KESIMPULAN Simpulan}

Berdasarkan hasil analisa data penelitian serta pembahasan yang telah dilakukan, maka sebagai jawaban dari permasalahan yang ada dalam penelitian ini dapat disimpulkan sebagai berikut :

Dari hasil penelitian diketahui bahwa terdapat hubungan positif kuat yang signifikan antara Budaya Organisasi Sekolah dan Motivasi Kerja Guru terhadap Mutu Pendidikan pada SD ISLAM TERPADU BAITUL JIHAD KEMANG PRATAMA 2, BEKASI, baik secara sendiri-sendiri maupun bersamasama.

Berdasarkan hasil analisa regresi maka didapati fakta bahwa faktor Motivasi Kerja Guru adalah faktor yang akan memberikan kontribusi terbesar terhadap peningkatan Mutu Pendidikan pada SD ISLAM TERPADU BAITUL JIHAD KEMANG PRATAMA 2, BEKASI.

\section{Saran}

Saran-saran yang dapat Penulis sampaikan terkait dengan hasil penelitian pada SD ISLAM TERPADU BAITUL JIHAD KEMANG PRATAMA 2, BEKASI, antara lain yaitu:

1. SD ISLAM TERPADU BAITUL JIHAD KEMANG PRATAMA 2, BEKASI harus membangun budaya organisasi yang berorientasi orang yaitu Sekolah harus menghasilkan keputusan manajemen yang memperhitungkan efek hasil pada orang-orang didalam organisasi Sekolah tersebut. Dengan demikian Sekolah harus merancang sebuah program yang berpengaruh langsung terhadap peningkatan 
kinerja Guru, misalnya pelatihan, workshop, seminar, penataran, pemberian beasiswa untuk melanjutkan pendidikan ke jenjang yang lebih tinggi pemberian reward, sehingga Guru terdorong untuk meningkatkan kinerjanya karena ada perhatian dan penghargaan. Budaya organisasi pada SD ISLAM TERPADU BAITUL JIHAD KEMANG PRATAMA 2, BEKASI hendaknya bukan seperti di Sekolah-sekolah yang menekankan kepada untungrugi suatu usaha. Walaupun demikian, Sekolah tetap memperhitungkan segi benefit (kebermanfaatan suatu usaha), hal ini berimplikasi pada profit Kepala Sekolah dan para Guru yang lebih sebagai pemimpin dan pendidik yang memiliki amanah menciptakan budaya positif yang relevan dengan produktivitas Sekolah, mewujudkan mutu pendidikan yang unggul, dan berhasil menciptakan lulusan yang berkualitas. Budaya organisasi pada SD ISLAM TERPADU BAITUL JIHAD KEMANG PRATAMA 2, BEKASI haruslah merupakan nilai-nilai, kepercayaan, dan tindakan sebagai hasil kesepakatan bersama yang melahirkan komitmen seluruh personil Sekolah untuk melaksanakannya secara konsekuen dan konsisten. Realisasi budaya organisasi tergantung pada bagaimana Kepala Sekolah menanamkan dan membudayakan di lingkungan Sekolah.

2. Terkait dengan peningkatan motivasi kerja Guru, ada sejumlah usaha praktis yang perlu dilakukan antara lain sebagai berikut :

- Memperbesar tanggungjawab, kedisiplinan, dan orientasi prestasi dalam pelaksanaan tugas-tugas Guru di Sekolah. Guru yang bermotivasi kerja tinggi betangungjawab, berdisiplin, dan berorientasi prestasi dalam melaksanakan tugas-tugasnya. Karakteristik ini harus ditumbuhkan pada diri setiap Guru, bisa melalui pelatihan atau menerapkan kebijakan yang mengarah pada penghargaan terhadap tanggungjawab, kedisplinan, atau orientasi prestasi dalam berkerja.

Menjadikan tanggungjawab, kedisiplinan, dan orientasi prestasi sebagai indikator kinerja Guru dalam melaksanakan tugasnya. Dengan cara demikian, para Guru akan terpaksa untuk melaksanakan tugas dengan motivasi kerja yang tinggi, karena penilaian terhadap motivasi kerjanya akan menentukan bagi kesinambungan karirnya sebagai Guru.

\section{DAFTAR PUSTAKA}

B. Suryosubroto, 2004, Manajemen Pendidikan di Sekolah, Jakarta: Rineka Cipta..

Departemen Pendidikan Nasional, Manajemen. 2002, Peningkatan Mutu Berbasis Sekolah Konsep Dasar, Ditjend Pendidikan Dasar dan Menengah, Ditjen SLTP, Jakarta.

Edy Sutrisno, 2009, Manajemen Sumber Daya Manusia, Jakarta: Kencana.

Gibson, James. L, dkk, 1993, Organisasi dan Manajemen; Perilaku, Struktur dan Proses Jakarta: Penerbit Erlangga.

Hamalik, Oemar, 2003, Proses Belajar Mengajar, Jakarta: Bumi Aksara.

Hasibuan, Malayu SP, 1996. Organisasi dan Motivasi, Dasar Peningkatan Produktivitas, Jakarta: Bumi Aksara.

Handoko, T. Hani,2012, Manajemen Personalia dan Sumber Daya Manusia (Edisi 12), Badan Penerbit Fakultas Ekonomi (BPFE-UGM), Yogyakarta.

J. Winardi, 2014, Motivasi dan Pemotivasi dalam Manajemen, RajaGrafindo Persada, Jakarta. Silalahi, Bennett, Corporate Culture \& Performance Appraisal, Sekolah 
Tinggi Ilmu Manajemen LPMI, Jakarta.

Siagian P. Sondang, 2005, Teori Motivasi dan Aplikasinya, Jakarta: PT. Rineka Cipta.

Tim Redaksi Fokusmedia, Undangundang RI No. 20 Tahun 2003 tentang SISDIKDAS (Sistem Pendidikan Nasional), 2003, Bandung: Fokusmedia.

Tisnawati Sule, Ernie dan Kurniawan Saefullah, 2014, Pengantar
Manajemen, Edisi Pertama. Jakarta: Prenadamedia Group.

Wibowo, 2010 , Budaya Organisasi : Sebuah Kebutuhan Untuk Meningkatkan Kinerja Jangka Panjang, Edisi Pertama, Rajawali Pers, Jakarta.

Wirawan, 2007, Budaya dan Iklim Organisasi, Salemba Empat, Jakarta. 